\title{
The Family as the Centre of Moral Values and Ethics: Challenges since the Covid-19 Pandemic
}

\author{
Prof. E. R. Mathipa \\ Department of Science and Technology Education \\ University of South Africa \\ E-mail: rajabalala@gmail.com \\ Prof. M. Z. Ramorola \\ Department of Science and Technology Education \\ University of South Africa \\ Dr. Q. M. Motsepe \\ School of Language Education \\ North-West University, South Africa
}

Doi:

\begin{abstract}
Nation-states are a result of the existence of families which constitutes communities that form them. Therefore, without families, regardless of how developed they are, there can't be communities, and, thus, no nation-states. Religiously argued, the family is the cardinal centre of focus when the wellbeing of a nation-state is to be assessed. Implying that, when families disintegrate, the survival of communities and of nations cannot be guaranteed. Precisely because of this, the family is a primary institution where religious, socio-economic and moral values are imparted to children who ultimately constitute future generations. To unravel dilemmas caused by the devastation of Covid19 pandemic on families, Maslow's theory and also that of nihilism are utilised in tandem with the principles and values that are underpinned by Rossouw's theory. The article aims to preserve the family as an important unit whose core functions is the production of communities. Religiously, diverse belief systems have from time immemorial used and or applied their principles and moral values to either overcome or manage dangers faced by families, or communities at large. Currently, the effects of Covid-19 on the economy, society, religious and learning institutions including essential establishments that delivers critical services are either under great pressure or have stopped functioning entirely. No question, Covid-19 is slowly but surely eroding and altering the way the world's people are living. It has introduced modes of survival hitherto known or which were never practiced before.
\end{abstract}

Keywords: Family, centre, moral values, ethics, Covid-19 pandemic.

\section{Introduction}

We kick-start our discourse by problematizing an issue that has been troubling society in the form of an ongoing conundrum manifested through the power relationship between religion and politics, and between the clergy and politicians. To problematize the issues even further we cite https://www.break.ma/news/30086897 accessed on 29/07/2021, which states that "almost half of South Africans trust prayer more than vaccines". As the controversies and contestations are raging, it should be borne in mind that "no education is provided to make the population literate in political affairs" (Cloete, 1993:1). Lack of political education is a huge disadvantage as this article will attest. The theme: Religion, communication and Covid-19 pandemic comes as a blessing because through it, many views, ideas, perceptions and arguments will be aired regarding: 
The family, as the germ-cell of society, is of the greatest importance in education. Nothing can entirely replace its function and all other educational institutions can only supplement. In a lovingly regulated family the small child receives his decisive moral values (Jalkotzy, 1963: 237).

In problematizing the issue even more we cite the latest report in which it is alleged that prisoners are refusing to be vaccinated as they believe that the vaccine is 'a mark of a beast, 666, Satanism. This matter is clearly captured in https://www.break.ma/news/301133 and in response Josia Ramokoena, Free State and Northern Cape Correctional Service Spokesperson is cited as pointing out that:

Inmates have a right to refuse the vaccine.

(https://www.break.ma/news/301133 accessed on 29/07/2021).

In the light of the above controversies, it is interesting to discover that even some of the medical insurance companies like Discovery are also making the threat that: "clients who indicate they are unwilling to be vaccinated may be subject to higher premiums due to increased risk". (https://www.break.ma.news/301196 accessed on the 29/07/2021).

As though that is not enough, the other unpalatable news that are coming out of https://www. News24/medical/infections-diseases.coronavirus/understanding-covid-19-vaccines-what-you-needtoknow-aboutbreakthrough-infections-2021108004-3 are amongst the many that:

Vaccination does not completely protect you against infection, but if you do
get Covid-19, you are likely to avoid severe illness and death...infection
occurs in just a fraction of vaccinated persons and accounts for a very small
percentage of Covid-19 cases. https://www. News24/medical/infections-
diseases.coronavirus/understanding-covid-19-vaccines-what-you-need-
toknow-aboutbreakthrough-infections-2021108004-3 accessed on 07/08/2021.

So people are left with a cloud of doubt hanging in their minds as to whether they should change and go for the vaccine or not. The theme: Religion, communication and Covid-19 pandemic, invokes memories of a minefield that is having layers upon layers of controversies and contestations. For instance, the available Covid-19 vaccines are neither a cure nor a prevention from being affected in the future. Then, we read in https://from news24com-deliv. accessed on 04/08/2021 that "South African drug regular evaluating medical records of 28 people who died after vaccine shot". Another troubling matter is that CDC says: "roughly 4,100 people have been hospitalised or died with Covid breakthrough infections after vaccination" (https://from cnbc.com-deliver. accessed on 04/08/2021.

To date, it appears that Covid-19 is even defying cutting-edge medical innovations meant to cure it. A clueless situation characterised by desperateness seem to be brewing instead of one of faith and hope. Dollar (1994:13) aptly said "in fact, fear always rushes in when faith is not present". Without trying to exhaust the least, it is sufficient to reveal that, thus far a lot of threats are now being also directed against those teachers who refuse to be vaccinated. Such teachers are deemed to be a danger to the school population. Threats are also directed to those who are staying in residential complexes as they are warned that they will be thrown out if they are not vaccinated. To make an illustration of this, let us read from https://www.groundup.org.za accessed on 12/08/2021 which reports that: "It appears in at least one instance that a landlord has threatened to evict tenants who refuse to get vaccinated".

In reaction, Zackie Achmet in https://www.groundup.org.za accessed on 12/08/2021 had this to say against the Commission which had come up in support of the tenant who refused to take the vaccine and he said the following: "The Human Rights Commission is wrong: vaccines are not always optional. The Commission is undermining the state's vaccine programme".

Sasol too, has decided to embark on a mass vaccination drive as it appears in https://www.news24.com>Topics accessed on 06/08/2021 which reported that: "Employees of chemicals company Sasol are up in arms about its plans for mass vaccination, but the company 
says it is simply trying to prevent the annual shutdown process of its Secunda plant from turning into a super-spreader event".

In the face of all these threatening, frightening and distressing messages about Covid-19, the official line of communication is not that positive and effective to allay fear. To this end, Schuitema (1994:43) instructively advises that "a tenet of popular wisdom holds that good managers communicate". Communication is key to the exchange of views and also to imparting of information, where communication is poor, important information is unlikely to reach those who need it mostly or badly. Covid-19 has become an enigma which is riddled with misinformation, controversies, disagreement and threats rather than clear answers to questions such as: what coronavirus is? Where did it originate? Why is it attacking people? And why there is no cure to arrest it from spreading unabatedly? All these troubling questions are not being addressed appropriately and adequately; and what remains is that people are fed with lots and lots of highly confusing messages.

Pursuing the above scenario of disagreements and contestations, it might falsely be concluded that in future no one will have the right to refuse to be vaccinated because those not vaccinated will be unable to access public transport, public facilities, or even get a job. These are possible realities that those who are against vaccination should think about. Moreover, certain countries have decided to close their borders to those countries whose people are highly affected by Covid-19. Given all these controversies, disagreements and threats, it is fair to conclude that Covid-19 pandemic has unfortunately succeeded in dividing the world populations into sharply opposed camps. Without doubt, social cohesion as highly sought after outcome, and it is unlikely to be achieved as desired. To be blunt, Covid-19 has succeeded in promoting a dichotomous situation in which communities have been divided into those who are in favour of being vaccinated and those who are against being vaccinated. In this article, we have decided to zoom on the family as the main factor under the spotlight, simply because: "Today our nation suffers from a sickness of the soul because families are weak. Weak in their knowledge of God. Weak in their convictions about God. Weak in their experience of God. Weak in their understanding of how to love one another" (Rainey, 2002:1).

Agreed that it is not only the religious issues that are affecting the family either negatively or positively. In this instance, we were given a host of themes to choose from, and we decided to choose the one that reads thus: Religion, communication and Covid-19 pandemic. To make it more relevant to the issues afflicting the family, we have deliberately added the socio-economic factors as being of paramount importance in the survival of families. However, under such dubious and taxing circumstances, we take solace in the fact that: "Family is God's plan for life on earth. All the social and political problems in the world could be significantly reduced if family life was improved' (Oliver 2014: 13).

The conditions and situations under which the theme dictates how we should argue is better described at length by Owen (1953: 20) who posited that:

\footnotetext{
Liberty, or human freedom, is temporal, limited, derived and dependent. It is by nature relative, cultural, historical, and conditioned. We speak of personal, social, civic, national, international, political, ecclesiastical, and religious liberty. Human freedom is associated with rights, privileges, duties, protection, security, responsibility, law, order, equality, and authority. Liberty is never absolute or unrestricted. The very conditions that create and sustain it also define and limit it (p. 20).
}

However, ever since the advent of the Covid-19 pandemic, religion has been on the receiving end from political meddling that is based on different levels of lockdown restriction of one sort or another. Covid-19 has now given rise to the officious behaviour of the politicians assuming intolerable levels of dictatorship in that religious establishments are being told how to run their own affairs. No doubt, this has negatively affected the principle of freedom of religion in more ways than one. This article aims to contribute some new perspectives of how to look at the family as an important unit that give rise to communities, who in turn constitute nations. To this end, Owen (1953:22) further to teaches that: 
Liberty cannot be fragmented or compartmentalised. Religious liberty is one of the means by which maximum human freedom is realised. Religious liberty is a means and not an end in itself.

If indeed religious liberty is described as a means to an end, then, it simply means that the means must be compatibly relevant and also adequate and proper for the achievement of the desired outcomes. To philosophise a bit, no bad tree can produce good fruits as there is no good tree that can produce bad fruits. Good outcomes will be impossible to achieve without good means. The dark side is that, the Covid-19 pandemic has inadvertently empowered politicians to now be in positions to dictate terms and conditions under which churches and other religious entities must operate. Such terms and conditions are accordingly the new means that the politicians have imposed on the churches. Apparently, were communication between the politicians and the clergy seems to have taken place, the outcome is invariably skewed in favour of the politicians. Politicians have used Covid-19 to alter the conditions under which societies live in one form or the other. In the majority of cases, these changes have left many of the middle of the road families at the mercy of hunger, poverty and also in very dire need. In this respect, Greeves (1961:21) has warned that: "Changes in the pattern of society profoundly affect the Church's mission, not because the essential nature of that mission varies, but because hindrances to, and opportunities for its fulfilment are modified".

Seen in the above light, Covid-19 appears to have, unfortunately, succeeded in creating conditions that have empowered politician to wield more power than the clergy. Religious liberty has as a result become highly curtailed at times, and the outcome of this is worth noting for it teaches that:

At the very center of religious liberty is freedom of worship, the right to worship God freely according to the dictates of one's conscience or tradition of one's faith. Religious liberty is freedom from ecclesiastical or political control and freedom to worship God as one wishes (Owen, 1953: 99).

Unfortunately, the prevailing conditions are such that under some of the strict regulations of the Covid-19 pandemic, freedom of religion is fast becoming a thing of the past as the government (politicians) now have the audacity to dictate circumstances under which churches can lawfully operate. Time and again, the different denominations are currently told how many numbers of their congregants can attend church and under what circumstances. Covid-19 has managed to reduce the number of congregations to a bare minimum of 50 members or where possible half the capacity of what their churches can accommodate.

Where the Covid-19 restrictions are disobeyed, the consequences for the disobeying them are dire. In a nutshell, under the Covid-19 restrictions, churches have gradually become empty, while on the other hand, the prisons are increasingly becoming full with people who disobey the Covid-19 restrictions that were imposed by government (politicians) to curb the spread of Covid-19. This is the backdrop that is characterising the discourse around the theme: Religion, communication and Covid-19 pandemic. These views are according to the authors' perspective and conceptualisation of the prevailing and or unfolding developments as dictated to by the nature, pace, degree and direction that Covid-19 takes from time to time. Thus, from time to time Covid-19 is able to communicate its presence through various statistics showing the death rate, the number of those who are affected, the number of those who have since recovered, and the number of those who are still being hospitalised.

On a lighter note, years ago, Owen (1953:6) brilliantly argued that "the Gospel is timely and timeless, changing but changeless." Meaning that what is subject to change is the cultural milieu under which the gospel is being practiced. Making it in turn, that the institutional life of the diverse religious belief systems being practiced be part and parcel of an embryonic cultural milieu of those countries that they are meant to serve. In this regard, Myburgh (1991:111) cites Hoebel (1949:405) who aptly argued that: "No culture is devoid of religion. Religious beliefs and customs are universal and belong to the religious aspect of culture".

Furthermore, what is both relevant and compatibly in alignment with the above thinking is the argument by Lewis (1992:68) who has brilliantly pointed out that: "Nothing distinguishes one 
community more sharply from another than its beliefs concerning the meaning of life, the position of men [humanity] in the universe, and the ultimate significance of affliction and suffering".

That said, there is no doubt that culture plays a very important role in the preservation of religion and also in the transmission of the gospel that it embodies. Then what is culture? While there are infinitely many different answers to the question, the answer by Owen (1953:26) is: "Culture is social heredity, that which we inherit from society and history. It is our 'invisible environment' of customs, attitudes, beliefs, codes of conduct, morals, points of view, ambitions, and traditions by and for which man lives".

The clear main message here is that within every culture there is a religion that is servicing the people who belong to it in the sense that:

\begin{abstract}
All religions postulate the existence of mystical powers in terms of which men endow their surroundings with ultimate, transcendental meaning. But religions also relate to man's social world and the moral rules which are the foundation and precondition of predictable and orderly social intercourse. (Lewis, 1992:145).
\end{abstract}

With the above expositions as constituting our informed understanding of the Covid-19 pandemic we are of opinion that a more analytic exercise into the literary sources that strictly define the main concepts underpinning the theme under the spotlight be undertaken. Therefore, what comes next is a discussion dealing with the definitions/descriptions/explanations of the concepts that underpin the theme and how these concepts are articulated in terms of their role of buttressing the various views and arguments put forward.

\title{
Definition of crucial underpinning concepts and their application
}

Concepts are important carriers of information and messages to and from, and on a day to day basis between and amongst individuals, organisations, communities and nations. The proper definition, description and explanation of the main concepts used in an article is of paramount significance in understanding the messages and information they are communicating. This is particularly true when dealing with a theme like: Religion, communication and Covid-19 pandemic. To get the ball rolling, what is meant by the term concept? In answer, Mouton and Marais (1990:58) aptly argued that: "Concepts are the most basic linguistic constructions by means of which people order and categorise reality. They are no less than 'pigeonholes' into which we sort the chaotic and unsystematised content of our experiences".

Concepts can be characterised as being devoid of direct sensory data but as arising from the interpretation of stored data which has been elaborated upon and also linked and combined to create meaningful symbols, codes and signs. Goldman (1968:11) in support points out that:
Conceptualising thus makes more sense by reducing the complexity of experience, by simplifying it, by making identification easier, by reducing the need for constant learning, by providing expectancy levels in behaviour and by later providing us with the ability to relate not only particular experiences together but classes of experience also.

That said, the concept religion has been well canvassed in the forgone subheadings. However, what remains is to define and also contextualise it in terms how it could bring families, communities and the nation together as a unit. After reading a host of books, we could not find a good definition of the concept religion except the one by Goldman (1968:4) who argues that:

\footnotetext{
Religion is the fulfilment of the entire man, of which his intellect is part...religion is the feelings, the acts and experiences of individual men...so far as they apprehend themselves to stand in relation to whatever they may consider the divine. This divine in our own culture is interpreted in terms of deity, and more specifically in terms of the Christian concept of God as love, revealed most fully in the historic fact of the Incarnation.
} 
To end the definitional aspect, we then went on to argue that each religion propagates a particular gospel that sustains it over ages as a motive force that is timeless and changeless. In support, Owen (1953:4) instructively educates us thus: "The Gospel is timely and timeless, changing but changeless. Christianity, on the other hand, particularly in its institutional life, displays the cultural phases of each age and country in which it has been planted. Thus we have many kinds of churches".

At face value, it could be interpreted to mean that, although the Gospel is timeless and changeless it has nevertheless been able to give rise to many different churches, and some of them are discussed later on in the relevant subheadings. However, it is important to also mention that:

\begin{abstract}
Every revealed religion is the religion and a religion, the religion in as much as it contains within itself the Truth and means of attaining the Truth, a religion since it emphasizes a particular aspect of the Truth in conformity with the spiritual and psychological needs of the humanity for whom it is destined and to whom it is addressed. (Seyyed, 1994:15).
\end{abstract}

Furthermore, it is important to note that, while the Gospel is timeless and changeless, however, the cultural milieu in which the Gospel is being practiced is of an ever-changing nature because culture is affected by time, place and the environmental factors. Not surprisingly therefore that, currently, the Covid-19 pandemic has drastically changed the way the people of the world used to live their lives. Having touched on the concept religion, it is logically also important touch on the word communication as well because it forms one of the three concepts of this discourse or theme. In this respect, Cleary (2007: vii) at length described it as follows:

\begin{abstract}
The term communication comes from the Latin word communicare, which means to make common. When you communicate you create common understanding between yourself and other people. Without communication, it would be impossible for you to relate to others around you. By using common symbols you are able to interact with other people and make yourself understood. (P. vii).
\end{abstract}

In the final analysis, Covid-19 is understood to be a virus that originated in China in 2019 and more specifically in the province of Wuhan. According to http://www.who.int>coronaviruse accessed on 23/07/2021 explains Covid-19 in the following words: "Covid-19 is a disease caused by a new strain of coronavirus. 'CO' stands for corona, ' $\mathrm{Vl}$ ' for virus, and ' $\mathrm{D}$ ' for disease. Formerly, this disease was referred to as '2019' novel coronavirus or '2019-nCoV".

The above descriptions, definitions and explanations aside, in going into substantial discussions regarding the wellbeing of an individual; it is important to quote Suma Ching Hai (1992:3) who instructively submits that:
By attaining inner peace we will attain everything else. All the satisfaction, all the fulfilment of worldly and heavenly desires come from the Kingdom of God- the inner realisation of our eternal harmony, of our eternal wisdom, and of our almighty power. If we do not get these we never find satisfaction, no matter how much money or power, or how high a position we have.

Now the problem faced by the world is that the Covid-19 pandemic has ushered in untold dislocations amongst the nations of the world by destroying families and communities.

The Covid-19 pandemic has a significant psychological and social effect on the community. The impact on the psychological well-being of the most exposed groups, which includes stress in children, students, and health workers, and it is huge as it is they who are more likely to develop post-traumatic stress disorder, anxiety attacks, depression, and a range of other symptoms. Especially families living in urban areas, find that their economic stability is lessened thus placing huge strains on the family unit. This is especially the case where children live at home with their parents (Cao et al., 2020). Also family members with virus infected relatives or acquaintances leads to a worsening in their anxiety and in their symptoms. 
To make matters worse, industries, institutions of learning, religious organisations and recreational activities have nearly stopped to function as planned and as expected. For example, major and key activities like politics, economics, sports, choral music competitions, funeral occasions and church going have become communicated through the virtual mode of online where possible. Like manna falling from the skies, this article finds expression at a time when many countries in various parts of the world have unfortunately followed the example of the:

\begin{abstract}
Many Western nations which have dramatically turned away from the Bible, becoming more secular and agnostic. Schools have not only eliminated the Bible and prayer from their schedules, but they have also gone on to become decidedly atheistic in their approach to education. Evolution is accepted, while religious instruction is outlawed (Taliaferro, 1973:1).
\end{abstract}

In another vein, Nasr (1966: xii) speaking for the Islam religion has categorically revealed his displeasure against the Islamic youth who lack an appreciation of Islamic knowledge, and he expressed himself as follows:
In many parts of the Islamic world, particularly in those countries where modern education is more prevalent, the younger generation has no knowledge of the intellectual and spiritual aspects of Islam, and is completely defenceless before the onslaught of modernisms. That is why with the first contact with Western science, philosophy or literature so many young Muslims lose their own tradition (P. xii).

The same can be said of African peoples who have since lost respect of their own religion, culture and medicines in favour of the Western ones. African states and their peoples have largely abandoned their traditional medicines and have instead opted to use western medicines to fight against Covid-19 pandemic. This is despite the fact that Africa as a whole is possessing many universities, doctors and scientists of its own. To add insult to injury, African leaders and their rich fellow travellers prefer western health facilities to their own and this provides a clear sign that they lack trust in the very health facilities they claim to be in charge of.

That said, in this article the authors accept the fact that, religion as a concept is broad as it encompasses such diverse belief systems as: Christianity, Buddhism, Hinduism, Baha'ism, Muslimism, Judaism, Atheism, and other forms in practice that operate in some parts of the world. In fact, Osborn (1965:17) has instructively pointed out that: "And for all the gentlemanly behaviour and Christian courtesy we can muster, denominations are in competition with one another. Each tends to become a self-serving device to build up the denomination rather than a response of love to the needs of men".

Therefore, in this article, the authors will attempt to be neutral as far as possible and borrow freely from any available information that can help to articulate the objectives of the theme under discussion better as and when they happen to come across it in the various religious belief systems mentioned above. In this respect, Little (2005:18) adds that: "Too often the Christian faith is not considered seriously, merely looked upon as one of a number of truth claims and not seen as built on any verifiable truth. Faith and superstition look like partners".

On the other hand, it is very important to acknowledge the point raised by Owen (1955:1) who has made the public aware that: "The merger of Marxist Communism and Russian imperialism, militantly atheistic and intolerant, has lifted the problem of religious liberty from a national to an international level".

What is liberal theology or what is sometimes called religious liberty? And the answer is found in (https://.thegospelcoalition.org accessed on 14/07/2021) and it states that: "Liberal theology is rooted in modern, secular theories of knowledge and has moved towards participation in the work of the church as the priority for Christians at the expense of delineating theological belief, which has led to the abandonment of many orthodox denominations". 
Seen in this context, can liberal theology assist the peoples of the world understand better how to arrest the spread of the Covid-19 pandemic? In order not to commit an unnecessary oversight, authors of this article have taken a deliberate view which they thought prudent in adopting a neutral position with regard to all the religious belief systems without preferring one above the others. However, the undisputable fact is that religion by its nature and activity is a phenomenon and it depends mainly on a mode of contact to communicate and spread its message to the multitudes that gather in places like churches, institutions of learning, funeral occasions, wedding ceremonies, birthday parties, and other important events. However, Covid-19 has gradually but certainly contributed to bringing an almost stop to such practices and events from taking place as it has a tendency to quickly spread itself faster at such occasions. Meaning that religion is no longer able to operate safely and optimally or even maximally as before.

No question, religion is a mode of communication between individuals and their Creator and through it people worship their Creator and give Him honour for showering them with His mercy and blessings. During times of crisis, such as the present scourge of the Covid-19 pandemic, the human wisdom becomes incapable of coping. Hence, the need by individuals to be religious increases in time of crisis because naturally man is a religious animal who knows the real fact that:

\begin{abstract}
Man lives a fleeting, fragile life in world marked everywhere by decay, disintegration and death. Materialistic and modernistic theology, which have nothing to offer man one moment after his death, cannot satisfy the inherent longing of the human soul for survival (Branham, 1950:20).
\end{abstract}

It is during time like such as this when individuals surrender themselves through prayer and song to their Creator asking to be delivered from the clutches of evil spirits in the form of diseases. Human beings are made of the body and soul and both need to be nourished in order to be content, restful and calm. That said, Erickson (1996:865) pointedly states that: The work of the Holy Spirit is of special interest to Christian, for it is particularly through this work that God is personally involved and active in the life of the believer.

To conclude this section, Hodge (1960:2) instructively and compellingly opens our mind to the fact that:

\begin{abstract}
A much higher kind of knowledge is thus obtained, than by mere accumulation of isolated facts. It is one thing, for example, to know that oceans, continents, islands, mountains, and rivers exist on the face of the earth; and a much higher thing to know are the causes which have determined the distribution of land and water on the surface of our globe; the figuration of the earth; the effects of that configuration on climate, on the races of plants and animals, on commerce, civilisation, and the destiny of nations.
\end{abstract}

The idea propagated here is that, it is not important to only know that there are various religions and that they spread their message or information through this or that mode of communication, than to understand the message they carry and what impact it has on the improvements of the wellbeing of the people who are meant to receive it. Here the liberal theologies unlike the traditional prophetic ones, have taken a stronghold on the minds of many believers in the modern times. These times are infested with diseases, hunger, unemployment, poverty, ignorance of the loving and merciful God but characterised by the promotion of jealousy, greed, rivalry and hatred.

The concept communication is capable of assuming many forms like the interpersonal type, the mass communication kind, public communication type, and others. The concept communication has also been comprehensively covered in the above sections and subheadings, nevertheless, it is still important to submit the fact that:

Communication is a two-way process that results in a shared meaning or common understanding between the sender and the receiver. The sender is involved in encoding the message which is decoded by the receiver. Feedback is the receiver's response to the message and can take various forms. (Cleary, 2007: 11). 
Despite the fact that the concept Covid-19 had been canvassed extensively in the forgone subheadings, it is still important to describe it in order to complete the section on the definitions under the chosen theme. As earlier cited, the virus called Covid-19 is a new strain of coronavirus that has not been previously identified in humans. It started in Wuhan, Hubei province, China where it caused an outbreak of respiratory illness. Coronaviruses are a large family of viruses that are known to cause illness ranging from the common cold to more severe diseases such as Severe Acute Respiratory syndrome (SARS) and Middle East Respiratory Syndrome (MERS).

Symptoms associated with Covid-19 which may appear within 2-14 days are the following: cough, fever, headache, new loss of taste or smell, repeated shaking with chills, sore throat, shortness of breath and muscle pain. To sum-up, the three concepts underpinning our chosen theme are discussed further as the pillars of what constitute the focal point of the process of literature review. That said, the next section treats the literature review to further interrogate the significance of the theme: Religion, communication and Covid-19 pandemic.

\section{Considering the Literature}

To begin with, the religious domain is like a minefield that is overloaded with controversies and arguments and counterarguments. To get a balanced and sound account of the claims and counterclaims we had to consult literature that goes as far back as we could possibly come across. However, we take as our point of emphasis the already canvassed view that the theme: Religion, communication and Covid-19 pandemic, is both political and ecclesiastical as it involves the state instructing religious institutions and including all and sundry as to how they should run their affairs under some of the demanding lockdown restrictions of the Covid-19 pandemic. The results of the lockdown restrictions are that most businesses and the livelihoods of people have literarily come to a standstill and in the process this brings about unemployment, poverty, hunger and anger- 'A hungry man is an angry man'.

By curtailing freedom of worship in order to curb the spread of Covid-19, the government is seen as interfering in the hard won human rights as embodied in the constitution and commonly referred to as "Freedom of religion, belief and opinion" (The Constitution of the Republic of South Africa, 1996: at page 8). Seen in this context, Owen (1953:9) vividly reminds us that: "The idea of religious liberty emerged as a result of a long series of relationships and adjustments between church and state. The history of the doctrine of church and state was background out of which the concept of religious freedom has come".

Our point of contention is that, religion is a phenomenon that is universally practiced by almost every individual, every family, community and nation; because by nature, man is a religious animal and when things overwhelm him he seeks the intervention of his Creator. Therefore, the restrictions that the state aim to impose on the religious establishments should be done after proper consultations. On this score, Greeves (1961:16) puts the matter succinctly by stating that: "We need the word 'soul', therefore, in order that we may be reminded of man's relationship to God and of his need for God".

In support, Newell (1997:8) also advises that "we must resolutely take time to pray, to get alone with God". Therefore, in this article our central argument is that for religious values and principles to become known and embraced by families, communities and nations, they need to be communicated without interference. Precisely because, communication is perceived as a major role-player in making religious values and principles gain a strong foothold in the individuals' conscience, and by extension, that of the community and the nation. To lay more emphasis, Mathipa et al, in Mathipa, Netshitangani and Matlabe (2017:31) point out that: "One's conscience acts like a compass indicating what is right or wrong, good or bad and acceptable or unacceptable".

What does the above teach us? After examining all the above, the authors saw it appropriate to cite the views of Gulliver (1979: 70) who is an authority on the art of negotiation, and he brilliantly pointed out that: 
The negotiating parties give each other information, directly or indirectly. Each engages in learning about the other, about himself, and about the possibilities and impossibilities of their common situation. Negotiation is a process of discovery. Discovery leads to some degree of reorganisation and adjustment of understanding, expectations, and behaviour, leading (if successful) eventually to more specific discussion about possible terms of a final, agreed outcome.

That being the case, before individuals can conquer the world around them, they need to first conquer themselves, humble themselves and strive after a life of peaceful coexistence. To this end, the South African Council for Educators Handbook for the Code of Professional Ethics produced by The Unilever Ethics Centre. University of Natal (2002: 27) has the following to offer:

Table 1.

\begin{tabular}{|l|l|l|l|l|}
\hline Islam & Christianity & Judaism & Hinduism & Buddhism \\
\hline No one of you is a & Do for others what you & What is & This is the sum of & Do not hurt \\
believer until he & want them to do for you & hateful to & duty: do nothing to & Others you \\
desires for his & you. This is the meaning & you, do not & others that would & yourselves \\
brother that & of the Law of Moses and & do to your & cause you pain if it & would find \\
which he desires for & the teachings of the & fellow man. & was done to you. & hurtful. \\
himself. (Sunan) & prophets. (The Bible) & (The Talmud) & (The Mahabarata) & (Udanavarga) \\
\hline
\end{tabular}

Adopted from the Handbook for the Code of Professional Ethics produced by The Unilever Ethics Centre. University of Natal (2002).

Despite such impeccable religious principles and ethical values espoused by the major different belief systems of the world: André Olivier (2001: 7) makes a startling revelation that: "When confronted with challenges some believers resort to prayer; not as a reliance on God, but as a way of abdicating their responsibility. It is as though God must do everything for them. It's a bit like asking God to tie your shoelaces. It's never going to happen! Most things require effort and responsibility on our part".

God created each individual with potential to become what he can become and ought to become if and only if he or she puts the necessary efforts to realise his or her God-given talent. However, individuals need each other to achieve their dreams because "...in recent years, networking and collaboration have become increasingly popular in education" (Ainscow, 2010:5). In another breath, Jooste (1996:51) is of opinion that communication that leads to friendship bonds is important in the sense that:

There is something in this life that is extremely precious to each one of us, whether we are Christians or not, and that is the value of friendship. True, dependable friends are hard to find and many people spend a lifetime working on and trying to perfect a single friendship, just to lose it when that person dies, relocate to a different town or city or develops an interest or occupation which is so time-consuming that special times become infrequent and eventually cease to exist.

To conclude this section on literature review based on various belief systems it is important to stimulate our minds through citing the words of Mathipa and Semuli (2012:76) when pointing out that:

To put networking in its proper context, people who wish to network must do so when aiming to achieve clearly defined goals. Even though such goals are subject to changes due to unknown circumstances; they are nevertheless needed, in order to network effectively.

Networking is an activity which relies heavily on communication because "communication is the process of creating meaning between two or more people through expression and interpretation of messages" (Cleary, 2007: vii). It is through communications that different nations of the world have from time immemorial been interacting with their various gods who they believed had power to grant 
them this or that kind of blessings, mercy, protection, cure, strength and so on. For-example, from Greek literature we learn that:

\begin{abstract}
The ancient Greeks did not know about the Bible. They did not know that there was a true God. They worshipped heathen gods like Zeus, whom they looked upon as the father of all gods and ruler of the world; Apollo, the god of light and music; and Athena, the goddess of wisdom (Grové, Le Roux, Dugard et al., 1971:100).
\end{abstract}

Seen in the above light, during ancient traditional times religion was according to Spiro as cited by Myburgh (1991:112) something very important, and he makes the claims that: "The religious aspect of culture is a system of beliefs and practices related to supernaturalism. It comprises culturally patterned interaction between man and culturally accepted supernatural being".

Indeed, religion amongst traditional cultures forms relationships between members of the community into a state of solidarity and cohesion that becomes a broad base for interactions that are legally recognised and cherished. In terms of black nations of the continent of Africa, their different cultures determine the names they give to their gods. For example, in the Southern Sotho languages their supernatural beings are in the form of ancestral spirits called badimo, while in the Nguni languages they called amadlozi and they highly honoured and worshipped through many acts and offerings. Such rituals take place during different times like at the advent of incurable diseases, or rainy seasons that introduces the ploughing times; and during events like circumcision, marriage, birth, death and many others such as the Covid-19 pandemic. Indigenous religions provide in many instances emotional outlets and thereby contributing immensely to the reduction of tension, stress and depression. Therefore, whatever limits their activities like the restrictions that are imposed due to attempts at arresting the dire consequences of Covid-19 pandemic will without question also drastically affect religious activities associated with worship and prayer. In all these events, communication which might be verbal or nonverbal plays a huge role in the lives of families, communities and nations in such processes as of interaction with the goal of coming together in order to share ideas, thoughts, projects and to offer assistance, motivation and wish each other the best under all circumstances. Therefore, seen within the above backdrop, religion and communication are vital weapons in the fight against Covid-19 in the sense that when people come together in prayer because "in knowing and loving God we shall achieve the purpose for which God made us" (Sheed, 1958:69). That said, the next section to follow is discussing the theoretical framework that undergird this article.

\title{
Theoretical Framework
}

The environment in which this article is written is characterised by a diversity of lockdown restrictions as a results of the spread of the Covid-19 pandemic which is affecting all countries without exception. To give an illustration of the various types or levels of lockdown restrictions, a selection of only levels one and five is presented. Lockdown/alert level one occupies the first extreme end of the continuum, while lockdown/alert level five occupies the other extreme end of the restrictions of the Covid-19 pandemic continuum. The two extremes are captured hereunder in the form of table 2.

Table 2.

\begin{tabular}{|l|l|}
\hline $\begin{array}{l}\text { LOCKDOWN LEVEL ONE: Disaster } \\
\text { Management Act Regulations. }\end{array}$ & $\begin{array}{l}\text { LOCKDOWN LEVEL FIVE: Disaster } \\
\text { Management Act Regulations. }\end{array}$ \\
\hline $\begin{array}{l}\text { 1.All Covid-19 health and safety protocols must } \\
\text { be followed at all times including observance of } \\
\text { guidelines for social distancing, sanitation and } \\
\text { hygiene, the use of personal protective } \\
\text { equipment, like cloth face masks. }\end{array}$ & $\begin{array}{l}\text { 1.All Covid-19 health and safety protocols must } \\
\text { be followed at all times including observance of } \\
\text { guidelines for social distancing, sanitation and } \\
\text { hygiene, and use of appropriate personal } \\
\text { protective equipment, like cloth face masks. }\end{array}$ \\
$\begin{array}{l}\text { 2.Most of the normal activity can resume, with precal } \\
\text { and health guidelines followed at all } \\
\text { times. }\end{array}$ & $\begin{array}{l}\text { 2. Alert Level five is the most restrictive of all the } \\
\text { alert levels, with only essential services permitted } \\
\text { under sectors. }\end{array}$ \\
\hline
\end{tabular}


3. Every person is confined to his or her place of residence from $00 \mathrm{H} 00$ until $04 \mathrm{H} 00$ daily, unless a person has been granted permission.

4. Any person who fails to abide by the curfew referred to in sub regulation (1) commits an offence and is, on conviction, liable to a fine, or a period of imprisonment not exceeding six months, or to both such fine and imprisonment.

5. Closing time for the following establishments, whether indoors or outdoors is $23 \mathrm{H} 00$ : for example, cinemas; theatres; casinos, museums etc.

6.Opening and closing of schools will be determined by the ministers responsible.

7.The wearing of masks is mandatory in public places. This exclude children of six years.

a) No person will be allowed to: use, operate, perform any service on any form of public transport;

b) Enter or be in a building, place or premises, including government buildings, places or premises, used by public to obtain goods or services: or

c) Be in any public space, if he or she is not wearing a face mask. etc.
3.Level five is essentially indicating that the material risk of health services being overwhelmed is actually present.

4. The higher the levels of the Covid-19 viruses the likelihood of the government imposing stricter measures.

5. Any person who fails to abide by the curfew referred to in sub-regulation (1) commits an offence and is, on conviction, liable to a fine, or a period of imprisonment not exceeding six months, or both such fine and imprisonment.

6.Closing time for the following establishment, whether indoors or outdoors is $23 \mathrm{H} 00$ : for example, cinemas; theatres, casinos, museums, etc.

7. Opening and closing of schools will be determined by the ministers responsible.

8. The wearing of masks is mandatory in public places. Excluding children of six yrs.

9. No person will be allowed to:

a) use, operate, perform any service on any form of public transport;

b) enter or be in a building, place or premise, including government buildings, places or premises, used by public to obtain goods or services: or be in any public space, if he or she is not wearing a face mask.

Synthesised from information gathered from https://www.gov.za>resources $>$ re accessed on 29/07/2021.

However, as already indicated in the abstract, this article has adopted Maslow's hierarchy of human needs, and the values and principles of Roussouw's theory, plus the theory of nihilism. To be more systematic, the article will first handle the theory of Maslow's hierarchy of needs which is represented in a form of a pyramid having the more basic needs at the bottom, while the more elaborate ones appear higher up the rung as can be seen clearly from Image 1 below.

\section{Maslow's Hierarchy of Needs}

For a good number of years the Maslow's theory has been extensively used to understand why different people behave as they actually do. It has also been used to predict certain behavioural tendencies amongst individuals and groups. A theory is a vital research tool for it serves as a basis upon which a researcher plans his or her research activities. Hence, Morrison (2007:12) argues that: "Theory gathers together all isolated bits of empirical data into a coherent concepyual framework for wider applicability".

A rheoretical platform affords researchers with the lenses that allow them to maintain focus on what needs be done in order to collect data and later to interpreting it in a systematic manner. Below is diagram1 depicting Maslow's hierarchy of needs. 


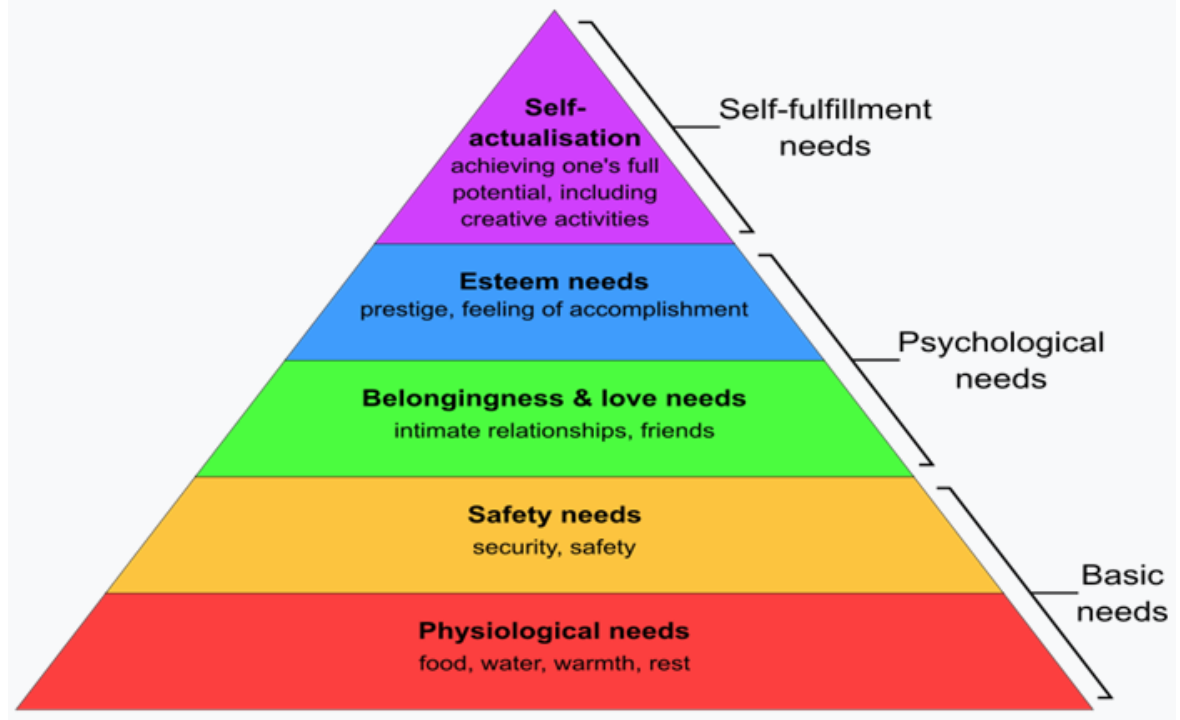

Image 1. Maslow's hierarchy of needs represented as a pyramid with the more basic needs at the bottom

All the basic needs in Maslow's theory play a vital role in describing and also identifying categories in which groups of people belong as per their real needs. For example, some people are in need of basic physiological needs that involve things such as food and water. These people may be described as the 'poorest of the poo'r. To contextualise the issue: "The looting in KwaZulu-Natal and Gauteng has a great deal to do with poverty and unemployment...hungry people will take any opportunity to grab what they can in a situationlike the country has experienced in the past few days" (The Citizen of 19/07/2021).

On the other hand, others require basic safety needs like security and safety which are in the form of such things as houses and clothes. In this respect, Billy Graham in Oliver (2014: 45) instructively opines that: "The family should be a closely knit group. The home should be a self-contained shelter of security; a kind of school where life's basic lessons are taught, a kind of church where God is honoured; a place where wholesome recreation and simple pleasures are enjoyed".

Then, there others wish to have basic needs like belongingness and intimate love or friendship. Jooste (1996:51) is beautiful when revealing the truth that: "There is something in this life that is extremely precious to each one of us, whether we are Christians or not, and that is the value of friendship".

From a spiritual perspective, for some believers this uncertainty is causing much anxiety. Christians would generally argue that according to Psalm 46: "God is our refuge and strength, a very present help in trouble. 2 Therefore will not we fear, though the earth be removed, and though the mountains be carried into the midst of the sea; 3 Though the waters thereof roar and be troubled, though the mountains shake with the swelling thereof. Selah".

Again, other people have self-esteem as their basic need, and these are the people who are driven by the urge and desire to achieve and accomplish. Hamachek (1990:52) instructively posits view that: "To some extent self-esteem (self-prizing, self-valuating) grows out of doing new things and doing them successfully".

On the other hand, Robert Crandall in Oliver (2001:17) describes the attitude of people who are driven by the desire to achieve as "I don't see any virtue in losing. This society rewards people who win". These are hardworking people who do not live just to eat. Unfortunately, today we have people in our midst who are after only state grants, RDP houses, free food parcels and so on and have no desire to work for a living.

Finally, there are those whose basic need is self-actualisation and they are driven by the spirit of self-discovery and self-realisation. Hamachek (1990: 55) has described people who desire to self- 
actualise in the following words: "Basically, the idea of self-actualisation refers to a person's constant striving to realise the potential within and to develop inherent talents and capabilities".

Riso and Hudson (2003:106-107) describe them as type three people and refer to them as: "Threes are the 'stars' of the personality types-people of tremendous drive, ambition, and a belief in themselves. Threes want to excel, to be the best at whatever they do, and they are willing to put in the effort it takes to do so".

To conclude our submission around the basic needs for self-actualisation it is of paramount importance to also cite Waitley (1996:1) when saying that: "Perhaps it's inherent in human nature to seek the security of living and working in a known environment, but in order to achieve success today you simply can't remain in your carefully constructed comfort zone".

The above views and arguments conclude the discussions around the role to be played by the theoretical framework of Maslow's hierarchy of needs. The next is the values and principles expressed by Roussouw's theoretical framework.

\section{Roussouw's theoretical platform of values and principles}

Diagram three below is a representation of the various theoretical values and principles as enunciated by Roussouw and adopted by Mathipa, Mampuru and Mukhari in a chapter appearing in academic book titled: Reflections on Professionalism, Pedagogy, and the Theoretical Underpinnings of Teaching Practice Revisited.

Table 3.

\begin{tabular}{|c|c|c|c|}
\hline $\begin{array}{l}\text { Principle Based } \\
\text { Theories }\end{array}$ & Virtue Based Theories & $\begin{array}{l}\text { Consequence Based } \\
\text { Theories }\end{array}$ & $\begin{array}{l}\text { Narrative Based } \\
\text { Theories }\end{array}$ \\
\hline $\begin{array}{l}\text { Principle-based- } \\
\text { theories are often } \\
\text { referred to as } \\
\text { deontological } \\
\text { theories, and they } \\
\text { stress that moral } \\
\text { actions should be } \\
\text { based on some } \\
\text { agreed rules or } \\
\text { code of conduct. }\end{array}$ & $\begin{array}{l}\text { Virtue-based-theories enjoin us } \\
\text { not to base our moral decisions } \\
\text { on the pain or pleasure those } \\
\text { actions might cause us. But we } \\
\text { should take rational control } \\
\text { over the emotions and natural } \\
\text { inclinations we experience as } \\
\text { we are confronted with } \\
\text { situations that demand moral } \\
\text { action from us. }\end{array}$ & $\begin{array}{l}\text { Consequence-based- } \\
\text { theories argue that } \\
\text { we should look at } \\
\text { the possible results } \\
\text { or practical } \\
\text { implications of our } \\
\text { intended actions in } \\
\text { order to determine } \\
\text { whether an action } \\
\text { is right or wrong. }\end{array}$ & $\begin{array}{l}\text { Narrative-based- } \\
\text { theories are like } \\
\text { religious ones, and do } \\
\text { not fit comfortably into } \\
\text { any of the above-cited } \\
\text { theories, even though } \\
\text { the other three have a } \\
\text { tendency to apply } \\
\text { narratives to their } \\
\text { own situations. }\end{array}$ \\
\hline
\end{tabular}

All the above theories are discussed in the spirit of their ability to offer individuals a monitoring mechanism to evaluate their decisions, thoughts, attitudes, behaviours and actions as to whether they are acceptable or not. They are also there to guide and also direct our decision-making capacities which are of paramount importance in building harmonious relationships between individuals, families, communities and nations. Clearly, these theories might on occasions be in competition with one another in attracting the individual's attention. This article intends to treat them as having an equal force of persuasion in determining our choices.

To put matters in perspective, all religious belief systems are an embodiment of specific noematic prescripts that are based on particular values and principles as constituting a regime of commandments to be followed. For instance, the Bible has the Ten Commandments. Joel Osteen 2011:7) is compelling when he discloses that: "The beauty of my father's life was that he was a man of great integrity. For me, that means he was the same at home as he was in church and whenever he was in front of other people. His sincerity had a tremendous impact on me and my siblings, and I'm sure it's a significant reason why today all five of us are working in the ministry".

The father is a head of the family and if he loses his bearings the family disintegrates. The next section discusses the indicators that drive the Covid-19 restrictions and prohibitions from time to 
time within the context of the theme: Religion, communication and Covid-19 pandemic. The theory of Nihilism follows.

\section{Nihilism as a theoretical framework}

Nihilism as a theory is quite uncommon or unpopular in academic circles because of its complexity albeit the fact that in real life it has a huge influence on the lives of a large number of people. People who due to their situations, circumstances, conditions and positions have come to the unfortunate conclusion that life for them is meaningless. Accordingly, Strauss and Cropsey (1972:795) point out that: "Nihilism is a protest against the approach of the last man. The formula for nihilism is: nothing is true, everything is permitted. Since all aspirations and ideals have proved meaningless, men cannot devote themselves to a cause: they have no future to will. Nihilists will nothingness rather than to desist from willing". Nihilism is thus a philosophy, which expresses a negation towards aspects of life that are widely accepted by people humanity as being objectively real, including for example knowledge, existence, and the meaning of life.

The word 'nihil' is a Latin term meaning nothing, while nihilism is a belief system that says even nothingness has real existence. The real argument of the nihilists is that nothing in this world is of any real substance. Briefly, to the nihilists life has no purpose to live for, and Osteen (2011:10) sums up the situation in this fashion: "Unfortunately, many men become convinced that their destiny is to suffer pain, disease, troubles, anxieties, and defeat". Nietzsche argued that its corrosive effects would ultimately destroy all moral, religious, and metaphysical convictions and bring about the greatest crisis ever faced in human history (Nietzsche, 1986).

The adherents of nihilism reject religious beliefs and principles, and they hold the view that there is no intrinsic meaning in life. In this world there are many people who have lost hope and lead purposeless lives under bridges, or who smoke terrible drugs, drink dangerous concoctions, and do evil deeds without thinking twice about any consequences. During the recent mayhem lots of people were seen to fearlessly burn business buildings, trucks transporting valuable property, school buildings, clinics, and many other valuable goods that they could not loot. They did not care whether they could be shot to death or not because life for them is meaningless.

When people experience a separation from their loved ones in the family, or a loss of freedom and being confined to set spaces, and have uncertainty about the Covid-19 virus, they may feel helpless (Li \& Wang, 2020). Such feelings that result may lead one to consider devastating actions (Weir, 2020), and some may consider taking their own lives in stressful situations (Mamun \& Griffiths, 2020). To place everything in context, even President Ramaphosa was heard confessing that they [the authorities] were taken by surprise regarding the scale of the damage that took place 'under the noses' of the police and the army. The Citizen (2021/07/19) is quoted as stating that: "Ramaphosa admitted in his address on Friday that they were poorly prepared for the looting, riots and public violence, which led to the death of over 200 people and damage to 161 malls and shopping centres last week". Thielicke (1969) wrote that: "Nihilism literally has only one truth to declare, namely, that ultimately Nothingness prevails and the world is meaningless".

Most of the rioting people did not fear death because as nihilists attest, life to them has no meaning. Illiteracy, unemployment and poverty has produced people who are popularly referred to as the 'poorest of the poor' and it is mainly these people who have lost hope and faith in life. The existence of such a class of people gives credence to the argument that, nihilism as a belief system has the potential to create a subculture whose adherents are fearless, heartless and a danger to social cohesion. What follows is a discussion on the triggers and indicators that prompt the introduction of the various Covid-19 lockdown restrictions.

\section{Discussion on triggers prompting the introduction of COVID-19 restrictions}

As already pointed out in table 1 the risk-adjusted measures which have been introduced from time to time have themselves been triggered by factors like the speed and intensity of the spread of the Covid-19 virus. Again, the availability of health facilities and resources also plays a major role in determining which Covid-19 restrictions to introduce. The need to measure the Covid-19 alert levels 
is captured by Rainey, (2002:16) who posits that: "First, if we want to reform the family we need standards. If there is no measuring mechanism, no 'spiritual yardstick,' how will we evaluate progress?".

That said, the introduction of lockdown level one restrictions is triggered by the low level of the spread of the Covid-19 virus. The implication is that the nature, scope and degree of the spread of the Covid19 virus is moderate and is far from threatening to overwhelm existing health facilities and resources. To reiterate, alert level one only contains mild restrictions which are of the first degree as compared to the rest. For further information the reader is referred to table 1 above. What is of paramount importance is the fact that under level one the Covid-19 restrictions allow the population the space to live their normal lives as far as possible. All that is needed at lockdown level one is for the individual to keep a good distance from the next person, to wear a mask in public space, to wash the hands with soap for 20 seconds and to sanitise as and when needed.

Lastly, it should be noted that Covid-19 virus is capable of changing from one structure to the other in order to adapt to the ever-changing environmental conditions. The ability to change from one structure to the next has huge implications to the pharmaceutical industries because they must strive at all times to produce a cure that is trustworthy, relevant, effective, of good quality and reliable. Furthermore, lockdown level one assures the population that the health facilities and resources are ready and available to accommodate more casualties of Covid-19 pandemic.

On the other hand, lockdown level two also indicates the extant nature, pace and the degree of the transmission of the Covid-19 is still quite mild. All that is needed at lockdown level two is to keep a good distance from the next person, to wear a mask, to wash hands with soap for 20 seconds and to sanitise as and when needed. The actual purpose of having lockdown level two, which constitutes the second stage, is to be able to plan ahead as how to contain the Covid-19 pandemic should it gain momentum. The planning must be geared to protect families because Rainey (2001:1) advises that: "no church, community, or nation will rise higher than the spiritual condition of its families". Lastly, stage two is also talking to the fact that the available health facilities and resources are far from being overwhelmed.

Lockdown level three marks the middle point of the continuum, and it is referred to as the third stage of the spread of Covid-19 virus. What does stage three tells is that the capacity of the health facilities and resources needed to accommodate the infected is reasonably available. Here everything is at the equilibrium point in terms of the spread of the Covid-19 virus and the available health facilities and resources. Apart from abiding with the already discussed lockdown restrictions, the movement of people from one province to the next is strictly monitored.

In lockdown level four which is also referred to as stage four, the ability of the public health interventions to arrest the spread of the Covid-19 pandemic begins to be under great stress or pressure. Apart from observing all the restrictions already alluded to earlier on, the gathering of people is restricted to specific numbers in different settings. Under lockdown level four businesses begin to suffer due to being hamstrung by the increased restrictions on the movement of people and goods. Furthermore, the introduction of curfew restrictions also have a negative influence as well as businesses and other institutions plus establishments were made to function below their normal capacities.

In addition, the gathering of people is highly regulated, and so too, is the monitoring of movement of people across provinces. To be precise, it is under lockdown level four where industries, learning institutions and other important events and activities are beginning to disintegrate leading to the collapse of small and medium industries. The results is an increase of unemployment, poverty, hunger, criminality, and the over-population of prisons. All these factors no doubt point to the disintegration of the family. Accordingly, Rainey (2001:1) reminds us thus:

The family is God's smallest unit in the battle for the soul of any nation. He designed the family as the birthplace and residence of Christianity. It is the place where knowledge, fear, and love of the Lord are taught by parents and 
learned by children. The family is where character is planted and grown. It is the place where civility and respect for others are nurtured and cultivated.

Finally, lockdown level five is the fifth and final stage in which the social, religious and economic activities are highly regulated as a means of curbing the spread of Covid-19 pandemic. According to the government, "the five-level COVID-19 alert system has been introduced to manage the gradual easing of the lockdown" (http://www.stateofthenation.gov.za accessed on 23/07/2021). The restrictions that are imposed during lockdown level are so stringent that even the churches begin to feel that their freedom to worship is being denied them. Owen (1953:17) indirectly but aptly cautions that:

Coercive power does not belong to the church, religious convictions cannot be forced. Nothing spiritual is of any advantage for eternal salvation to men under compulsion. Scripture may be used for teaching, argument, and correction, never for coercion and punishment.

To place the matter in perspective, alert/lockdown level one indicates a low level of the spread of the Covid-19 pandemic. On the other side, it also indicates that the health system's facilities and resources are not overburdened because few people are being admitted into its facilities. Again, it means that the family as an important unit of society and of the nation is not under threat of disintegration. In other words, it also means that the centre is still holding.

On the other hand, alert level two, like level one indicates a moderate level of the spread of Covid19 pandemic, meaning that the health facilities and resources are able to cope. In this regard, Greeves (1960) assures us that:

\begin{abstract}
A physician is interested in disease because he seeks to restore the patient to health, and health is the primary concern of those who follow in the footsteps of the good Physician. Christians should have no other interest in sin, whether their own or other people's, than the interest which looks to salvation.
\end{abstract}

Returning to (the) theme: Religion, communication and Covid-19 pandemic which directs and guides the discussions around issues of religion and communication, it is obvious that with the movement of people being curtailed to the minimum, then, verbal communication too, becomes noticeably restricted to a bare minimum as well. In addition, things like food and other essential means of sustenance which include the word of God that feeds the souls of the multitudes becomes also lost to the individuals who no longer can worship together as before.

In order to restrict the movement of people and goods, it has become common knowledge that as early as March of 2020 the entire police force and an army of 70,000 were unleashed by the government in order to implement the Covid-19 restrictions meant to arrest the spread of the pandemic. The police and the army were given orders not to argue but to arrest and sometimes to brutally punish those who unfortunately were thought to undermine law and order. An individual like Mr Collins Khosa was throttled to death. (dailymaverich.co.za accessed on 19/07/2021). This incident is captured by abovementioned source as follows: "Yet the numbers of people dead (11 plus Collins Khosa and Montsumi) and the reports of assault, police corruption and other police misdemeanours (376) were reported to Parliament by IPID which means they are facts, not allegations (the circumstances are all that is in contention, not the fact of the reports or the deaths) and which are now under investigation".

The Covid-19 restrictions are made to apply to all without exception, and the result is that people are staying home idling. Yet we ought to know that: idle hands are the tools of the devil. The moral of the idiom is that if you have nothing to do, you are prone to do some mischief. Briefly, an idle individual is likely to do something evil. The truth of this is the looting and mayhem that recently took place under the noses of the police and the army. To repeat, The Citizen (2021/07/19) is quoted as stating that: "Ramaphosa admitted in his address on Friday they were poorly prepared for the looting, riots and public violence, which led to the death of over 200 people and damage to 161 malls and shopping centres last week". 
Without much ado, we argue with many others that the repeated closure of businesses, industries, religious establishments and institutions of learnings at critical times of the year due to Covid-19 has exceedingly stopped individuals from leading productive lives. In the process many have found it impossible to realise their goals or dreams and they are experiencing one kind of frustration or anxiety, or depression. The point we are making here is to prove that Covid-19 brought about spiritual deprivation, depression and desperation due to lack of spiritual fulfilment plus a lack of things like food amongst the great masses who became jobless. To close the argument, it is mind boggling that South Africa which is a democracy with one of the best constitutions in the world is now witnessing looting and mayhem partly because many people are hungry, poor, unemployed and idle as a result of amongst others, the measures it has taken in that of fighting the Covid-19 pandemic. Whatever the arguments, people have been negatively affected by a lack of basic physiological needs like food, water and oxygen for the ill, which are no longer adequately provided for. Basic needs which include security and safety became two factors which can be dramitised/demonstrated by citing The Citizen (2021/07/19) which has captured the situation as follows: "The outbreak of violence, destruction and wanton looting in Kwa-Zulu-Natal (KZN) and some parts of Gauteng, sparked a whammy for South Africa: a brain-drain, further hampering of the economy, which KZN experiencing an exodus of people to the Western".

On the dark side, by curtailing movement and association through distancing and drastically reducing the number of people who wish to come together and console, congratulate or enjoy one another's company at places like funerals, wedding celebrations, graduations ceremonies, church services, sporting events, cinemas and many other events, people have become disillusioned. This has resulted in the unity of the family, community and nation being dislocated due to the Covid-19 pandemic and its challenges for society. With these dislocations, gone are the basic needs of belonging and love because these needs can only be expressed by the individual's bodily presence as characterised by warm hugs, kisses and sometimes tears.

The basic needs of self-esteem cannot and would never be expressed in isolation as Covid-19 is forcing people not to come together except in small groups of only young people as the elderly ones are debarred due to their vulnerability to contracting the Covid-19 virus. Older people are denied the usual opportunities of socialisation due to their vulnerability to the Covid-19 pandemic and they now feel unimportant or even valueless, if not disliked.

The last basic needs are of self-actualisation which is cardinal especially in the different professions where mentoring is a must in order for neophytes to achieve their dreams. Therefore, things like supervision, coaching, teaching, lecturing, educating and mentoring presupposes a coming together of some sort. However, Covid-19 has led to a stop to such contacts as institutions of learning are being closed down from time to time.

From a Christian perspective, our faith teaches us that God 'knows the end from the beginning', and so $\mathrm{He}$ is surprised by absolutely nothing. His holy word assures us that $\mathrm{He}$ is always with his people, no matter what they are going through. It also promises that when our lives end, we will receive a new body that can never be destroyed, and we will be with God in a place where there is no more mourning or crying or pain. The core principle of the Christian faith is that God became a human to share our ups and downs, our human frailty, all our sorrows and our mortality. He fully comprehends what we are going through, from an obedience perspective, the Holy Bible teaches us that we should for the most part always (in all but the most extreme situations) obey the government, and we will need to take seriously the measures that our leaders tell us to adopt. Scrupulously observing the stated measures is not simply a matter of our own protection, but by doing so we are helping and also protecting the most vulnerable in our society. We do however need to have answers to the questions posed in this article.

\section{Recommendations}

Communication and more communication is now needed more than ever before in order to inform and to educate all and sundry as to what the coronavirus is. 
People must be given true information about the life-span of the virus.

People need to be told under what conditions the Coronavirus reproduces and multiplies.

People need to know which interventions are available that can curb the spread of Coronavirus from one place to another and from one person to the next.

People need to know that apart from quarantine measures, what else can be used to better cure the infected.

People need to know why the existing vaccines are not a total cure or a full protection against the Coronavirus so that they do not refuse to get vaccinated as some do.

In conclusion, the above misgivings are not been adequately addressed, hence, the resistance from large numbers of people in many different countries. Again, there are stories going around discouraging people from taking the vaccine and very little is done to counter such narratives except ill-advised threats emanating from those in authority.

\section{References}

Ainscow, M. \& Sandill, A. (2010). Developing inclusive education systems: the role of organizational cultures and leaders. International Journal of Inclusive Education, 14(14), 104-11.

Cleary, S. (2007). The Communication Handbook. Cape Town: Juta Co. dailymaverich.co.za accessed on 19/07/2021

Cao, W., Fang, Z., Hou, G., Han, M., Xu, X., Dong, J., et al. (2020). The psychological impact of the COVID-19 epidemic on college students in China. Psychiatry Research, Volume 287, 112934. doi: 10.1016/j.psychres.2020.112934

Dollar, C. A. 1994. Uprooting the Spirit of Fear, New York: Harrison House, Inc.

Goldman, R. 1968. Religious Thinking from Childhood to Adolescence. London: Routledge \& Kegan Paul.

Erickson, M. J. 1985. Christian Theology. New York: Baker Book House. Vol. 3

Greeves, F. 1960. Theology and the cure of souls: An introduction to pastoral theology. London: The Epworth Press.

Grové, B. S., Le Roux, F. Dugard, J. \& Geyser, J. 1971. Revised Social Studies Form 1. Pretoria: Via Afrika Limited.

Gulliver, P, H. 1979. Disputes and Negotiations: A Cross-Cultural Perspective. New York: Academic Press.

Hai, S, C. 1996. The key of Immediate Enlightenment, Formosa: Suma Chiang Hai International Association Publishing Co.

Hamachek, D. 1989. Psychology in Teaching, Learning, and Growth, Boston: Allyn and Bacon.

Heed, F, J. 1958. Theology of beginners. London: Redwood Burn LTD.

Hodge, C. 1960. Systematic Theology. London: James Clark \& Co. LTD

Holy Bible. King James Version. HarperCollins Publishers.

Jalkotzy, A. 1963. School for parents. London: Galley Press LTD.

Jooste, C. 1996. Serving God: What's in it for you? Midrand: Orion Publishers. 
https://www.gov.za>resources>re accessed on 29/07/2021.

http://www.stateofthenation.gov.za accessed on 23/07/2021.

https://www.break.ma/new/30086897 accessed on 29/07/2021.

https://.thegospelcoalition.org accessed on 14/07/2021.

https://from cnbc.com-delivere accessed on 04/08/2021.

https://www.news24.com>Topics accessed on 06/08/2021

https://from news24com-deliv.accessed on 04/08/2021

https://www.break.ma/news/301133 accessed on 29/07/202.

(https://www.break.ma.news/301196 accessed on the 29/07/2021.

http://www.who.int>coronaviruse accessed on 23/07/2021

https://www.news24/medical/infections-diseases.coronavirus/understanding-covid-19-vaccineswhat-you-need-toknow-aboutbreakthrough-infections-2021108004-3 accessed on 07/08/2021.

https://www.groundup.org.za accessed on 12/08/2021

https://www.groundup.org.za accessed on 12/08/2021

Lewis, I. M.1992. Social Anthropology in Perspective, Cambridge: Cambridge University Press.

Li, L. Z. \& Wang, S. (2020). Prevalence and predictors of general psychiatric disorders and loneliness during COVID-19 in the United Kingdom. Psychiatry Research, 291, 0165-1781. doi: 10.1016/j.psychres.2020.113267

Lindsay, G. 1950. William Abraham A man sent from God, Durban: The Standard Bearer Publishing Co.

Little, P. E. 2005. Know why you believe, Paarl: Paarl Printers.

Mamun, M. A. \& Griffiths, M. D. (2020). First COVID-19 suicide case in Bangladesh due to fear of COVID-19 and xenophobia: Possible suicide prevention strategies, Asian Journal of Psychology, 51:102073. doi: 10.1016/j.ajp.2020.102073

Maslow, A. 1962. Hierarchy of Needs Theory, New York: Chapel Hill.

Mathipa, E.R. \& Semuli, Q. K. 2012. The Significance of Networking and Partnerships in Educational Research. Educational Research in South Africa: Practices and Perspectives. A paper in conference proceedings of the South African Education Research Association, Bela Bela: Ivyline Technologies (Pty) Ltd.

Mathipa, E, R., Netshitangani, T. \& Matlabe S. M. 2017. Reflections on Professionalism, Pedagogy and the Theoretical Underpinning of Teaching Practice Revisited. New York: Nova Publishers.

Mouton, J. \& Marais, H, C. 1990. Basic concepts in the methodology of social sciences, Pretoria: HSTC.

Myburgh, A. C. 1990. Papers on Indigenous Law in Southern Africa, Pretoria: van Schaik.

Myburgh, A. C. 1981. Anthropology for South Africa, Pretoria: J L Van Schaik.

Newell. P. R. 1997. Into His Presence, Illinois. Crossway Books.

Nietzsche, F. (1986). Human, All Too Human (Menschliches, Allzumenschliches [vol. 1], 1878 and [vol. 2], 1879-1880), trans. R. J. Hollingdale (Cambridge: Cambridge University Press, 
Northridge, W. L. 1938. Psychology and Pastoral Practice, London: The Epworth Press.

Olivier, A. 2001. Finding a way to win: Sandton: Struik Christian Books.

Olivier, A. 2002. Finding a way to win: Seven Keys to Success, Sandton: Struik Christian Books.

Olivier, A. 2014. Building strong families, Sandton: Breakthrough Ministries.

Osborn, R. E. 1965. A church for these times, London: Abington Press.

Osteen, J. 2011. Becoming a Man of Unwavering Faith, New York: Faith Words.

Owen, G. E. 1953. Faith and Freedom. Manila, The Philippine Federation of Christian Churches.

Radcliffe-Brown, A. R. 1979. Structure and Function in Primitive Society, Norfolk: Lowe and Brydone Printers Limited.

Rainey, D. 2002. Building Strong Families, Illinois: Crossway Books.

Riso, D. R, \& Hudson, R. 2003. Discovering your personality type, New York: Houghton Mifflin Company.

Seyyed, H, N. 1996. Ideas and realities of Islam, London: The Aquarian Press.

South African Council for Educators(2002). Handbook for the Code of Professional Ethics, Produced by The Unilever Ethics Centre

Strauss, L. \& Cropsey, J. 1972. History of political philosophy, Chicago: Rand McNally \&Company.

Taliaferro, M. 1984. God is making a comeback, Johannesburg: Zondervan Publishing House.

The Citizen of 2021/07/19.

Thielicke, H. (1969). Nihilism: Its Origin and Nature, with a Christian Answer, Religious Perspectives, 4.

Waitley, D. 1996. The New Dynamics of Goal Setting. London: Nicholas Brealey Publishers.

Weir, K. (2020). Grief and COVID-19: Mourning our bygonelives, Washington: American Psychological Association.

Williams, D. T. 1988. The sword, famine and pestilence: Expectation of health and prosperity in the prophets. In Old Testament Essays. 1(2).pp1-19. Menlo Park: Serva Publishers. 